DOI https://doi.org/10.30525/978-9934-588-92-1-68

\title{
ПРОБЛЕМА ЗАСТОСУВАННЯ «ТРИСКЛАДОВОГО ТЕСТУ» РОЗПОРЯДНИКАМИ ПУБЛІЧНОЇ ІНФОРМАЦІЇ
}

\author{
Скумбрій Д. О. \\ студент II курсу магістратури \\ Інституту права
}

Київського національного університету імені Тараса Шевченка

м. Київ, Украӥна

Закон України «Про доступ до публічної інформації» (далі - Закон) встановлює чіткі критерії для того, щоб віднести інформацію до інформації з обмеженим доступом. Більше того, критерії, котрі вказані в частині 2 статті 6 вказаного закону цілком відповідають європейським стандартам [2, с. 63]. 3 цього випливає, що органи державної влади мають досконалий інструментарій для того, щоб відносити інформацію 3 обмеженим доступом. Проте на практиці виникають проблеми, коли уповноважена особа при мотивуванні віднесення інформації до інформації з обмеженим доступом лише перераховує підстави, які вказані в ч. 2 ст. 6 Закону, проте недостатнім чином мотивує своє рішення.

Метою даної роботи є проведення аналізу практики Верховного Суду у справах про оскраження рішення посадових осіб під час віднесення інформації до службової інформації. Другим аспектом мети роботи $є$ пропозиція щодо покращення практики віднесення інформації до інформації з обмеженим доступом.

У постанові пленуму Вищого адміністративного суду № 10 від 29 вересня 2016 р. (далі - Постанова) міститься чіткий перелік того, як органи державної влади повинні аргументувати своє рішення обмежити доступ до інформації. У цій Постанові до кожного пункту частини другої статті шостої Закону було надано «дорожню карту», якою мала б керуватись уповноважена особа. Було встановлено, що в першу чергу уповноважена особа повинна встановити, якому інтересу (із переліку встановленого п. 1 ч. 2 ст. 6 Закону) загрожує публічна інформація, а також потрібно встановити, як обмеження інформації сприятиме захисту такого інтересу. Другий крок уповноваженої особи встановити, в чому полягає можлива шкода інтересам внаслідок розкриття інформації. Більше того, на цьому етапі необхідно зазначити причинно-наслідковий зв'язок між розкриттям публічної інформації та 
шкодою, котру може зазнати інтерес. Останнім кроком уповноваженої особи є пояснення, чому шкода від відкриття доступу до інформації переважає суспільний інтерес в іiі отриманні [1, ст. 142]. Саме такий порядок дій $\epsilon$ єдиноправильним під час обмеження публічної інформації.

Проте на практиці виникають кардинально інші ситуації, незважаючи на наявність чіткої інструкції у Постанові. Більшість розпорядників інформації, як свідчить судова практика, лише цитують критерії обмеження доступу до публічної інформації, проте не мотивують таке обмеження так, як про це вказано у Постанові. Більше того, навіть Верховний Суд не завжди дотримується чіткого мотивувального алгоритму при винесенні рішень. Наприклад, у рішеннях у справах № 9901/510/18 від 14.06.2018; № 800/552/17 від 08.02.2018; № 800/592/17 від 29.01.2018 Верховний Суд у повній мірі здійснює лише перший крок з інструкції, яка викладена в Постанові. Тобто Верховний Суд пояснює, якому інтересу відповідає обмеження доступу до публічної інформації та в чому полягає істотна шкода, яка може бути завдана такому інтересу внаслідок розкриття інформації, проте далі у цих же рішеннях лише вказує на те, що цим інтересам може бути завдана шкода та те, що суспільний інтерес не переважає над розкриттям інформації.

Як вбачається із викладеного вище, проблема із застосуванням трискладового тесту існує не лише на рівні розпорядників публічної інформації, але й навіть у практиці Верховного Суду. Відсутність єдиної практики щодо застосування критеріїв «трискладового тесту» негативно впливає на принципи доступу до публічної інформації. Крім цього відсутність єдиної судової практики в цьому питанні призводить негативно впливає на авторитет розпорядників публічної інформації, тому що вони не мають чіткого та усталеного орієнтиру правильних дій під час обмеження доступу до інформації. Сдиним орієнтиром залишається вищезгадана Постанова, проте на неї, як видно із перелічених вище рішень, не завжди звертається увага органаами державної влади.

На мою думку, показовим прикладом того, як повинна відбуватись мотивація обмеження доступу до публічної інформації з урахуванням коментарів у п. 6.2 Постанови відображена в мотивувальній частині рішення Верховного Суду № 800/552/17 від 08.02.2018 року. В даній справі відповідачем було обмежено доступ до правильних відповідей з тестів у конкурсі на посаду судді. У своєму рішенні суд провів аналіз на підставі ч. 2 ст. 6, а саме суд не просто перерахував критерії, за якими відповідач правомірно обмежив доступ до публічної інформації, а виклав 278 
аргументовану позицію, чому обмеження інформації відповідає критеріям трискладового тексту. Так, суд вказав, що інформація, до котрої розпорядник обмежив доступ, має характер конфіденційної інформації та може нанести негативно вплинути на анонімність джерела такої інформації. Далі колегія суддів встановила, що шкода від розкриття інформації може проявитись у підриву авторитету до кваліфікаційного тесту на зайняття посади судді через розголошення таємниці тестування. I останнім кроком суду була аргументація того, що шкода у вигляді підриву авторитету суддівського корпусу та кваліфікаційоного тесту на зайняття посади судді, очевидно, $\epsilon$ значно вищою від суспільного інтересу щодо розкриття такої інформації.

Отже, як вбачається, існує проблема відсутності єдності серед розпорядників публічної інформації, а також серед суддів Верховного Суду щодо застосування трискладового тесту на практиці. На жаль, вказані суб'єкти в більшості випадків лише цитують положення ч. 2 ст.6 Закону, проте не розкривають суті своїх аргументів на користь обмеження доступу до інформації. В даному випадку було б доцільно наголосити на важливості п. 6.2 Постанови. На основі положень, котрі викладені в п. 6.2 Постанови. можна доповнити класичну схему розуміння «трискладового тесту» та зробити механізм обмеження доступу до публічної інформації конкретним та чітким. У такому випадку при кожному застосуванні трискладового тесту, розпорядник інформації міг би відповідати на питання, які містяться у п. 6.2 Постанови, що мало б позитивний ефект на практику віднесення інформації до інформації з обмеженим доступом.

\section{Література:}

1. Заярний О.А. Суб'єкт адміністративних правопорушень у сфері доступу до публічної інформації: Законодавчі підходи та проблеми правозастосовної інтерпритації. Eurasian Academic Research Journal. 2017. № 2. C. 137-145.

2. Костова Н. І. Доступ до публічної інформації в українському зконодавстві та за законодавством країн СС. Часопис иивілістики. 2017. №. 24. C. $62-65$ 